\title{
Anti-hepatitis B virus activity of Boehmeria nivea leaf extracts in human HepG2.2.15 cells
}

\author{
JINGCHEN WEI ${ }^{1}$, LIANKU LIN ${ }^{2}$, XIAOJIAN SU ${ }^{3}$, SHAOYAN QIN $^{3}$, QING XU ${ }^{1}$, \\ ZUNIAN TANG $^{1}$, YAN DENG ${ }^{1}$, YUEHAN ZHOU ${ }^{1}$ and SONGQING HE YE $^{2,4}$ \\ ${ }^{1}$ Department of Pharmacology, Guilin Medical University, Guilin, Guangxi 541004; ${ }^{2}$ Laboratory of Hepatobiliary \\ and Pancreatic Surgery, Affiliated Hospital of Guilin Medical University, Guilin, Guangxi 541001; \\ ${ }^{3}$ College of Resources and Environment, Guangxi Normal University, Guilin, Guangxi 541004; \\ ${ }^{4}$ Guangxi Key Laboratory of Molecular Medicine in Liver Injury and Repair, Affiliated \\ Guilin Medical University, Guilin, Guangxi 541001, P.R. China
}

Received October 14, 2013; Accepted November 08, 2013

DOI: $10.3892 /$ br.2013.205

\begin{abstract}
Boehmeria nivea (Linn.) Gaudich of the Urticaceae family is a perennial ratoon herbal plant, the root of which is used in traditional Chinese medicine and possesses a variety of pharmacological properties. The $20 \%$ ethanol Boehmeria nivea root extract was shown to exert an anti-hepatitis B virus (HBV) effect in vitro and in vivo; however, whether the Boehmeria nivea leaf (BNL) extract possesses similar properties has not been determined. In this study, we aimed to investigate the anti-HBV effects of the BNL extract in HepG2.2.15 cells transfected with human HBV DNA. Our results demonstrated that the secretion of $\mathrm{HBsAg}$ and $\mathrm{HBeAg}$ was reduced in HepG2.2.15 cells treated with the BNL extract, without any recorded cytotoxic effects. In addition, the chloroform fraction (CF) and ethyl acetate fraction (EAF) of BNL were shown to be more potent compared to the other fractions: CF (100 mg/l) inhibited the secretion of HBsAg by $94.00 \pm 1.78 \%$ [inhibitory concentration $50\left(\mathrm{IC}_{50}\right)=20.92 \mathrm{mg} / \mathrm{l}$ ] and that of $\mathrm{HBeAg}$ by $100.19 \pm 0.35 \%\left(\mathrm{IC}_{50}=19.67 \mathrm{mg} / \mathrm{l}\right)$ after 9 days of treatment. Similarly, EAF (200 mg/l) inhibited the secretion of $\mathrm{HBsAg}$ by $89.95 \pm 2.26 \%\left(\mathrm{IC}_{50}=39.90 \mathrm{mg} / \mathrm{l}\right)$ and that of $\mathrm{HBeAg}$ by $98.90 \pm 1.42 \%\left(\mathrm{IC}_{50}=36.45 \mathrm{mg} / \mathrm{l}\right)$. Furthermore, we observed that the content of HBV DNA in the medium secreted by the HepG2.2.15 cells was significantly decreased under CF (100 mg/l) or EAF (200 mg/l) treatment. Thus, we
\end{abstract}

Correspondence to: Dr Songqing He, Laboratory of Hepatobiliary and Pancreatic Surgery, Affiliated Hospital of Guilin Medical University, Guilin, Guangxi 541001, P.R. China

E-mail: dr_hesongqing@163.com

Abbreviations: BNL, Boehmeria nivea leaf; HBV, hepatitis $\mathrm{B}$ virus; PEF, petroleum ether fraction; $\mathrm{CF}$, chloroform fraction; $\mathrm{EAF}$, ethyl acetate fraction; $\mathrm{nBF}, \mathrm{n}$-butanol fraction; $\mathrm{AF}$, aqueous fraction

Key words: Boehmeria nivea leaf, hepatitis B virus, HepG2.2.15 cell, HBsAg, HBeAg, hepatitis B virus DNA concluded that the BNL extracts exhibited anti-HBV activity, with $\mathrm{CF}$ and EAF being the most potent among the fractions.

\section{Introduction}

Boehmeria nivea (Linn.) Gaudich of the Urticaceae family is a perennial ratoon herbal plant, also referred to as home ramie, white linen or round hemp. The root of this plant is used as a traditional Chinese herbal medicine and possesses a variety of pharmacological properties. Over the last few years, the medicinal value of the Boehmeria nivea (Linn.) Gaudich has attracted increasing attention. It was previously determined that Boehmeria nivea (Linn.) Gaudich contains triterpenes, polyphenols, flavonoids, chlorogenic acid, quercetin, ursolic acid and other ingredients (1), some of which were shown to exert antitumor (2-4), antiviral (5-7), antibacterial (8), hepatoprotective, glucose-lowering (9) and antioxidant effects (10). Huang et al (5-7) reported that the $20 \%$ ethanol Boehmeria nivea root extract exhibited anti-hepatitis $\mathrm{B}$ virus (HBV) activity in vitro and in vivo; however, whether the Boehmeria nivea leaf (BNL) extract possesses similar properties has not been determined. In this study, we aimed to investigate the anti-HBV effects of the BNL extract in HepG2.2.15 cells transfected with human HBV DNA.

\section{Materials and methods}

Reagents. MTT, dimethyl sulfoxide (DMSO) and G418 were purchased from Sigma (St. Louis, MO, USA). The ELISA kit for HBsAg and HbeAg was obtained from the Sino-American Biotechnology Company (Luoyang, China). The HBV DNA extraction and amplification fluorescence assay kit was purchased from Guangzhou Da An Gene Co.,Ltd. of Sun Yat-Sen University (Guangzhou, China). High-glucose Dulbecco's modified Eagles medium (DMEM), trypsin, EDTA, L-glutamine and fetal bovine serum (FBS) were purchased from Gibco-BRL (Carlsbad, CA, USA). Lamivudine, also referred to as 2'-3'deoxy-3'-thiocytidine (3TC), was obtained from GlaxoSmithKline Pharmaceuticals Co., Ltd. (Brentford, UK) and freshly prepared before use. 


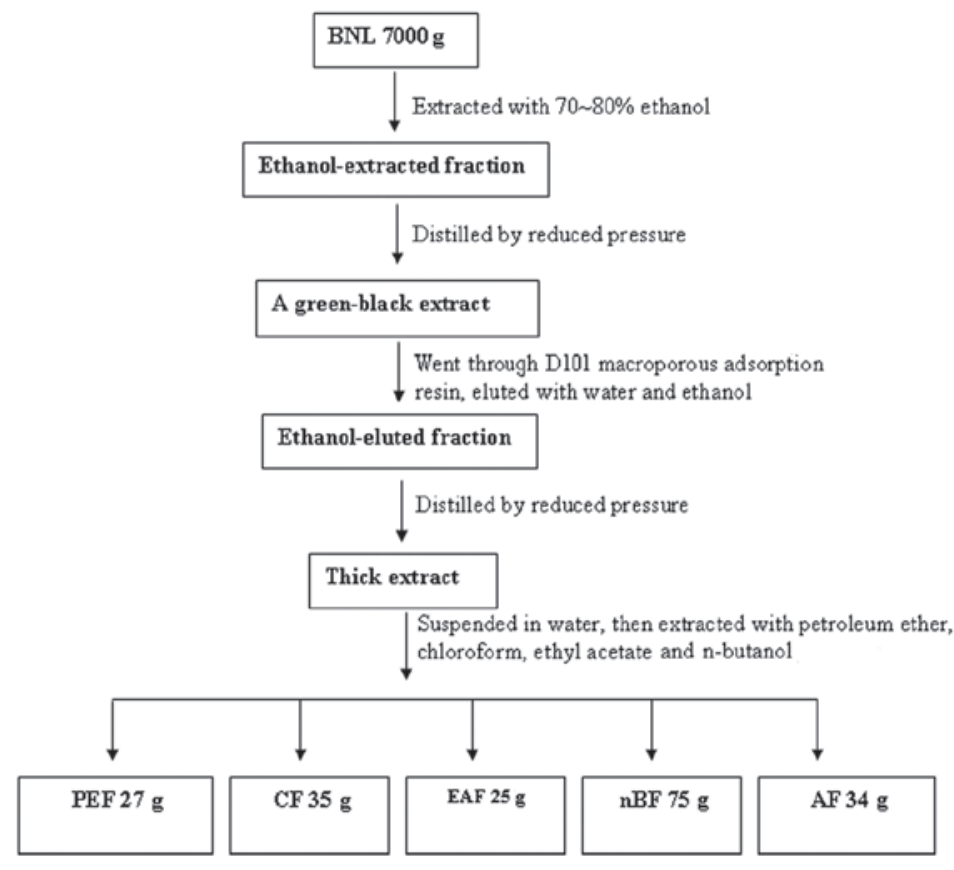

Figure 1. BNL extraction procedure. Dried BNL ( $7 \mathrm{~kg}$ ) was extracted in a stepwise procedure. Finally, $27 \mathrm{~g}$ of petroleum ether, $35 \mathrm{~g}$ of chloroform, $25 \mathrm{~g}$ of ethyl acetate, $75 \mathrm{~g}$ of $\mathrm{n}$-butanol and $34 \mathrm{~g}$ of aqueous extracts were harvested. BNL Boehmeria nivea leaf; PEF, petroleum ether fraction; $\mathrm{CF}$, chloroform fraction; EAF, ethyl acetate fraction; nBF, n-butanol fraction; $\mathrm{AF}$, aqueous fraction.

BNL extraction. The Boehmeria nivea (Linn.) Gaudich used in this study was grown in the suburbs of Guilin (Guangxi, China) and the leaves were collected. The protocol for the extraction of the BNL fractions is summarized in Fig. 1. Briefly, the components of BNL were obtained with reflux extraction from $7 \mathrm{~kg}$ of dried leaves with $70-80 \%$ ethanol three times. The extracts were then pooled, concentrated by reduced pressure and went through D101 macroporous adsorption resin (Tianjin Science and Technology Co., Ltd, Tianjin, China) followed by water and ethanol elution. The ethanol-eluted fraction was enriched and $240 \mathrm{~g}$ of extract was obtained. The extract was then diluted with water and stirred thoroughly to yield a turbid suspension. The suspension was extracted with petroleum ether, chloroform, ethyl acetate and n-butanol, respectively. Finally, 27, 35, 25, 75 and $34 \mathrm{~g}$ of petroleum ether, chloroform, ethyl acetate, n-butanol and aqueous extracts, respectively, were harvested.

Qualitative analysis of the chemical compositions of the BNL extracts. Five fractions extracted from BNL [petroleum ether fraction (PEF), chloroform fraction ( $\mathrm{CF}$ ), ethyl acetate fraction (EAR), n-butanol fraction (nBF) and aqueous fraction (AF)] were dissolved in ethanol and their chemical compositions were assayed qualitatively, as described previously (5-7).

Cell culture and drug treatment. HepG2.2.15 cells transfected with human HBV DNA were provided by the Beijing No. 302 Hospital and maintained in DMEM supplemented with $10 \% \mathrm{FBS}, 1 \%$ penicillin/streptomycin and $200 \mathrm{mg} / 1 \mathrm{G} 418$ in a humidified atmosphere of $5 \% \mathrm{CO}_{2}$ at $37^{\circ} \mathrm{C}$. For treatment, $1 \times 10^{4}$ cells were seeded in a 96-well plate and cultured for $24 \mathrm{~h}$ prior to extract addition. The extracts were dissolved in DMSO and diluted to proper concentrations. The medium was changed three times every 3 days using fresh medium containing the corresponding extracts. At different time points (3, 6 and 9 days), medium was collected and stored at $-20^{\circ} \mathrm{C}$ until use. Under the same conditions, a blank group was used as the negative control and $3 \mathrm{TC}$ as the positive control.

MTT assay. In order to investigate the cytotoxic effects of the BNL extracts, the MTT assay was used. Briefly, the HepG2.2.15 cells were seeded in a 96-well plate and treated with the different extracts for 9 days. Following treatment, the medium was replaced with an equal volume of fresh medium containing $5 \mathrm{mg} / \mathrm{ml} \mathrm{MTT}$ and the plate was incubated for $4 \mathrm{~h}$ at $37^{\circ} \mathrm{C}$. The MTT was removed and the cells were lysed with DMSO. The dark blue formazan crystals formed in intact cells were solubilized by shaking for $15 \mathrm{~min}$ and the absorbance at $570 \mathrm{~nm}$ was measured with an Elx800 type ELISA analyzer microplate reader (BioTek Instruments, Inc., Winooski, VT, USA). The cell growth rate was expressed as a percentage of the control.

ELISA. HBsAg and HBeAg in the conditioned medium were quantified using two antibody sandwich ELISA kits (Sino-American Biotechnology Company), according to the protocol provided by the manufacturer.

Quantitative fluorescence polymerase chain reaction ( $Q F-P C R)$. The amount of HBV DNA in the cultured medium was measured by QF-PCR. Total RNA was extracted from HepG2.2.15 cells treated with different concentrations of $\mathrm{CF}(12.5,25,50$ and $100 \mathrm{mg} / \mathrm{l}), \mathrm{EAF}(25,50,100$ and $200 \mathrm{mg} / \mathrm{l})$ and 3TC (positive control; 25, 50,200 mg/l) for 3,6 and 9 days, using TRIzol reagent (Invitrogen, Carlsbad, CA, USA). The primers used in this study were as follows: P1, 5 'ATCCTGCTGCTATGCCTCATCTT 3'; P2, 5' ACAGTGGGGGAAAGCCCTACGAA 3'; fluorescent 
Table I. $\mathrm{IC}_{50}(\mathrm{mg} / \mathrm{l})$ of extracted BNL fractions on HBsAg and HBeAg secretion from HepG2.2.15 cells.

\begin{tabular}{|c|c|c|c|c|c|c|}
\hline \multirow[b]{2}{*}{ Fractions } & \multicolumn{3}{|c|}{ HBsAg (days) } & \multicolumn{3}{|c|}{ HBeAg (days) } \\
\hline & 3 & 6 & 9 & 3 & 6 & 9 \\
\hline PEF & - & 176.30 & 73.00 & - & 130.10 & 94.73 \\
\hline $\mathrm{CF}$ & - & 33.43 & 20.92 & 77.90 & 28.05 & 19.67 \\
\hline EAF & 143.00 & 52.90 & 39.90 & 93.30 & 67.82 & 36.45 \\
\hline $\mathrm{nBF}$ & - & - & 103.10 & - & 127.51 & 63.48 \\
\hline $\mathrm{AF}$ & - & - & - & 21.38 & 133.07 & 157.12 \\
\hline $3 \mathrm{TC}$ & - & - & 86.80 & - & - & 29.44 \\
\hline
\end{tabular}

$\mathrm{IC}_{50}$, inhibitory concentration 50; BNL, Boehmeria nivea leaf; PEF, petroleum ether fraction; CF, chloroform fraction; EAF, ethyl acetate fraction; nBF, n-butanol fraction; AF, aqueous fraction; 3TC, 2'-3'deoxy-3'-thiocytidine.

Table II. Effects of CF and EAF from BNL on the inhibition of HBsAg secretion by HepG2.2.15 cells ( $\mathrm{n}=3$ ).

\begin{tabular}{|c|c|c|c|c|c|c|c|c|}
\hline \multirow[b]{2}{*}{ Groups } & \multirow[b]{2}{*}{$\begin{array}{c}\text { Concentration } \\
(\mathrm{mg} / \mathrm{l})\end{array}$} & \multicolumn{2}{|c|}{3 days } & \multicolumn{2}{|c|}{6 days } & \multicolumn{2}{|c|}{9 days } & \multirow{2}{*}{ 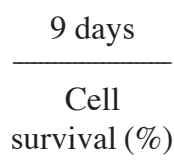 } \\
\hline & & OD & $\begin{array}{c}\text { Inhibition } \\
(\%)\end{array}$ & OD & $\begin{array}{c}\text { Inhibition } \\
(\%)\end{array}$ & OD & $\begin{array}{c}\text { Inhibition } \\
(\%)\end{array}$ & \\
\hline Control & & $1.434 \pm 0.249$ & - & $1.206 \pm 0.328$ & - & $0.549 \pm 0.128$ & - & 100.00 \\
\hline \multirow[t]{4}{*}{$\mathrm{CF}$} & 100 & $0.822 \pm 0.176^{\mathrm{a}}$ & $44.1 \pm 12.71$ & $0.203 \pm 0.079^{\mathrm{a}}$ & $88.68 \pm 6.96$ & $0.100 \pm 0.009^{b}$ & $94.00 \pm 1.78$ & 115.92 \\
\hline & 50 & $1.130 \pm 0.224$ & $21.92 \pm 16.15$ & $0.511 \pm 0.188$ & $61.45 \pm 16.61$ & $0.146 \pm 0.010^{\mathrm{b}}$ & $84.37 \pm 2.18$ & 98.24 \\
\hline & 25 & $1.241 \pm 0.099$ & $13.94 \pm 7.11$ & $0.690 \pm 0.194$ & $45.59 \pm 14.52$ & $0.199 \pm 0.013^{b}$ & $73.14 \pm 2.73$ & 87.86 \\
\hline & 12.5 & $1.224 \pm 0.251$ & $15.14 \pm 18.13$ & $1.064 \pm 0.231$ & $12.56 \pm 20.41$ & $0.457 \pm 0.074$ & $19.27 \pm 15.43$ & 129.90 \\
\hline \multirow[t]{4}{*}{ EAF } & 200 & $1.087 \pm 0.201^{\mathrm{b}}$ & $56.81 \pm 8.50$ & $0.253 \pm 0.072^{b}$ & $84.29 \pm 6.39$ & $0.119 \pm 0.011^{\mathrm{b}}$ & $89.95 \pm 2.26$ & 97.36 \\
\hline & 100 & $0.853 \pm 0.065^{\mathrm{a}}$ & $41.86 \pm 4.72$ & $0.460 \pm 0.126^{\mathrm{a}}$ & $65.93 \pm 11.10$ & $0.174 \pm 0.036^{\mathrm{b}}$ & $78.37 \pm 7.53$ & 74.23 \\
\hline & 50 & $1.041 \pm 0.037$ & $28.33 \pm 2.69$ & $0.600 \pm 0.104$ & $53.55 \pm 9.16$ & $0.238 \pm 0.017$ & $64.97 \pm 3.60$ & 76.96 \\
\hline & 25 & $1.244 \pm 0.158$ & $13.67 \pm 11.39$ & $0.910 \pm 0.062$ & $26.20 \pm 5.44$ & $0.406 \pm 0.007^{\mathrm{a}}$ & $29.80 \pm 1.49$ & 67.63 \\
\hline \multirow[t]{4}{*}{$3 \mathrm{TC}$} & 200 & $0.910 \pm 0.110^{\mathrm{a}}$ & $37.78 \pm 7.97$ & $0.699 \pm 0.062^{\mathrm{a}}$ & $44.83 \pm 5.44$ & $0.258 \pm 0.017^{\mathrm{a}}$ & $60.92 \pm 3.48$ & 76.87 \\
\hline & 100 & $0.974 \pm 0.202$ & $33.14 \pm 14.55$ & $0.826 \pm 0.136$ & $33.63 \pm 12.07$ & $0.283 \pm 0.073$ & $55.62 \pm 15.26$ & 67.19 \\
\hline & 50 & $1.100 \pm 0.196$ & $24.08 \pm 14.13$ & $0.962 \pm 0.021$ & $21.60 \pm 1.86$ & $0.358 \pm 0.062$ & $39.92 \pm 12.99$ & 78.54 \\
\hline & 25 & $1.295 \pm 0.177$ & $10.00 \pm 12.79$ & $1.273 \pm 0.111$ & $-5.95 \pm 9.85$ & $0.698 \pm 0.079$ & $-31.18 \pm 16.43$ & 125.86 \\
\hline
\end{tabular}

Data are presented as means \pm standard error of the mean. ${ }^{\mathrm{a}} \mathrm{P}<0.05$ and ${ }^{\mathrm{b}} \mathrm{P}<0.01 \mathrm{vs}$. control. OD, optical density; $\mathrm{CF}$, chloroform fraction; EAF, ethyl acetate fraction; BNL, Boehmeria nivea leaf; 3TC, 2'-3'deoxy-3'-thiocytidine.

probe sequence, 5' GGCTAGTTTACTAGTGCCATTTG 3'. The amplification parameters included predegeneration at $93^{\circ} \mathrm{C}$ for $2 \mathrm{~min}$, followed by 10 cycles of denaturation at $93^{\circ} \mathrm{C}$ for $45 \mathrm{sec}$ and annealing at $55^{\circ} \mathrm{C}$ for $1 \mathrm{~min}$; the condition was then changed to 30 cycles of denaturation at $93^{\circ} \mathrm{C}$ for $30 \mathrm{sec}$ and annealing at $55^{\circ} \mathrm{C}$ for $45 \mathrm{sec}$.

Statistical analysis. Data are presented as the means \pm standard error of the mean and the Student's t-test was applied for statistical analysis to determine the statistical significance. $\mathrm{P}<0.05$ was considered to indicate a statistically significant difference.

\section{Results}

Inhibitory effect of the BNL extracts on $\mathrm{HBSA} g$ and $\mathrm{HBeAg}$ secretion by HepG2.2.15 cells. To investigate the effects of the BNL extracts on HBsAg and HBeAg secretion by HepG2.2.15 cells, we first determined the inhibitory concentration $50\left(\mathrm{IC}_{50}\right)$ of the different BNL extracts. As shown in Table I, the CF was the most potent inhibitor of HBsAg and HBeAg secretion, followed by EAF. Of note, the AF was more efficient in inhibiting the HBeAg secretion by HepG2.2.15 cells at the 3-day time point compared to other extracts and other time points. In addition, we observed that $\mathrm{CF}$ and EAF inhibited HBsAg (Table II) and HBeAg (Table III) secretion by HepG2.2.15 cells in a concentration- and time-dependent manner. After 9 days of CF treatment $(100 \mathrm{mg} / \mathrm{l})$, the secretion of $\mathrm{HBsAg}$ was reduced by $94.00 \pm 1.78 \%$ and that of HBeAg by $100.19 \pm 0.35 \%$ (Tables II and III, respectively). Furthermore, after 9 days of EAF treatment $(200 \mathrm{mg} / \mathrm{l})$, the secretion of HBsAg and HBeAg was reduced by $89.95 \pm 2.26$ and $98.90 \pm 1.42 \%$, respectively (Tables II and III). 
Table III. Effects of CF and EAF from BNL on the inhibition of HBeAg secretion by HepG2.2.15 cells ( $\mathrm{n}=3$ ).

\begin{tabular}{|c|c|c|c|c|c|c|c|c|}
\hline \multirow[b]{2}{*}{ Groups } & \multirow[b]{2}{*}{$\begin{array}{c}\text { Concentration } \\
(\mathrm{mg} / \mathrm{l})\end{array}$} & \multicolumn{2}{|c|}{3 days } & \multicolumn{2}{|c|}{6 days } & \multicolumn{2}{|c|}{9 days } & \multirow{2}{*}{ 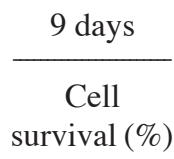 } \\
\hline & & OD & $\begin{array}{c}\text { Inhibition } \\
(\%)\end{array}$ & OD & $\begin{array}{c}\text { Inhibition } \\
(\%)\end{array}$ & OD & $\begin{array}{c}\text { Inhibition } \\
(\%)\end{array}$ & \\
\hline Control & & $2.948 \pm 0.135$ & - & $2.660 \pm 0.315$ & - & $1.088 \pm 0.229$ & - & 100.00 \\
\hline \multirow[t]{4}{*}{$\mathrm{CF}$} & 100 & $1.248 \pm 0.226^{\mathrm{a}}$ & $58.77 \pm 7.83$ & $0.323 \pm 0.137^{\mathrm{a}}$ & $89.52 \pm 5.25$ & $0.057 \pm 0.004^{\mathrm{a}}$ & $100.19 \pm 0.35$ & 115.92 \\
\hline & 50 & $1.901 \pm 0.291^{\mathrm{a}}$ & $36.19 \pm 10.06$ & $0.953 \pm 0.256^{\mathrm{a}}$ & $65.39 \pm 9.79$ & $0.145 \pm 0.027^{\mathrm{a}}$ & $91.67 \pm 2.67$ & 98.24 \\
\hline & 25 & $2.183 \pm 0.102^{\mathrm{a}}$ & $26.45 \pm 3.54$ & $1.453 \pm 0.332^{\mathrm{a}}$ & $46.24 \pm 12.72$ & $0.253 \pm 0.007^{\mathrm{a}}$ & $81.18 \pm 0.70$ & 87.86 \\
\hline & 12.5 & $2.410 \pm 0.296^{\mathrm{b}}$ & $18.59 \pm 10.23$ & $2.055 \pm 0.330$ & $23.18 \pm 12.63$ & $0.930 \pm 0.174$ & $15.32 \pm 16.9$ & 129.90 \\
\hline \multirow[t]{4}{*}{ EAF } & 200 & $0.820 \pm 0.216^{\mathrm{a}}$ & $73.57 \pm 7.46$ & $0.340 \pm 0.108^{a}$ & $88.87 \pm 4.13$ & $0.070 \pm 0.015^{\mathrm{a}}$ & $98.90 \pm 1.42$ & 97.36 \\
\hline & 100 & $1.499 \pm 0.314^{\mathrm{a}}$ & $50.09 \pm 10.87$ & $0.988 \pm 0.184^{\mathrm{a}}$ & $64.04 \pm 7.03$ & $0.160 \pm 0.050^{\mathrm{a}}$ & $90.15 \pm 4.86$ & 74.23 \\
\hline & 50 & $2.120 \pm 0.142^{\mathrm{a}}$ & $28.63 \pm 4.91$ & $1.495 \pm 0.139^{b}$ & $44.63 \pm 5.33$ & $0.347 \pm 0.029^{b}$ & $71.98 \pm 2.85$ & 76.96 \\
\hline & 25 & $2.398 \pm 0.182^{b}$ & $19.02 \pm 6.28$ & $2.383 \pm 0.219$ & $10.60 \pm 8.39$ & $0.809 \pm 0.075$ & $27.15 \pm 7.29$ & 67.63 \\
\hline \multirow[t]{4}{*}{$3 \mathrm{TC}$} & 200 & $1.752 \pm 0.330^{\mathrm{a}}$ & $41.34 \pm 11.40$ & $1.814 \pm 0.151^{\mathrm{b}}$ & $32.39 \pm 5.77$ & $0.358 \pm 0.017^{\mathrm{b}}$ & $80.69 \pm 1.62$ & 76.87 \\
\hline & 100 & $1.901 \pm 0.420$ & $36.19 \pm 14.53$ & $2.058 \pm 0.384$ & $23.06 \pm 14.72$ & $0.283 \pm 0.073$ & $78.23 \pm 7.09$ & 67.19 \\
\hline & 50 & $2.126 \pm 0.478$ & $28.42 \pm 16.53$ & $2.203 \pm 0.204$ & $17.50 \pm 7.80$ & $0.358 \pm 0.062$ & $70.94 \pm 6.03$ & 78.54 \\
\hline & 25 & $2.388 \pm 0.176$ & $19.38 \pm 6.07$ & $2.596 \pm 0.199$ & $2.44 \pm 7.61$ & $0.698 \pm 0.079$ & $37.93 \pm 7.63$ & 125.86 \\
\hline
\end{tabular}

Data are presented as means \pm standard error of the mean. ${ }^{a} \mathrm{P}<0.01$ and ${ }^{\mathrm{b}} \mathrm{P}<0.05$ vs. control. OD, optical density; CF, chloroform fraction; EAF, ethyl acetate fraction; BNL, Boehmeria nivea leaf; 3TC, 2'-3'deoxy-3'-thiocytidine.
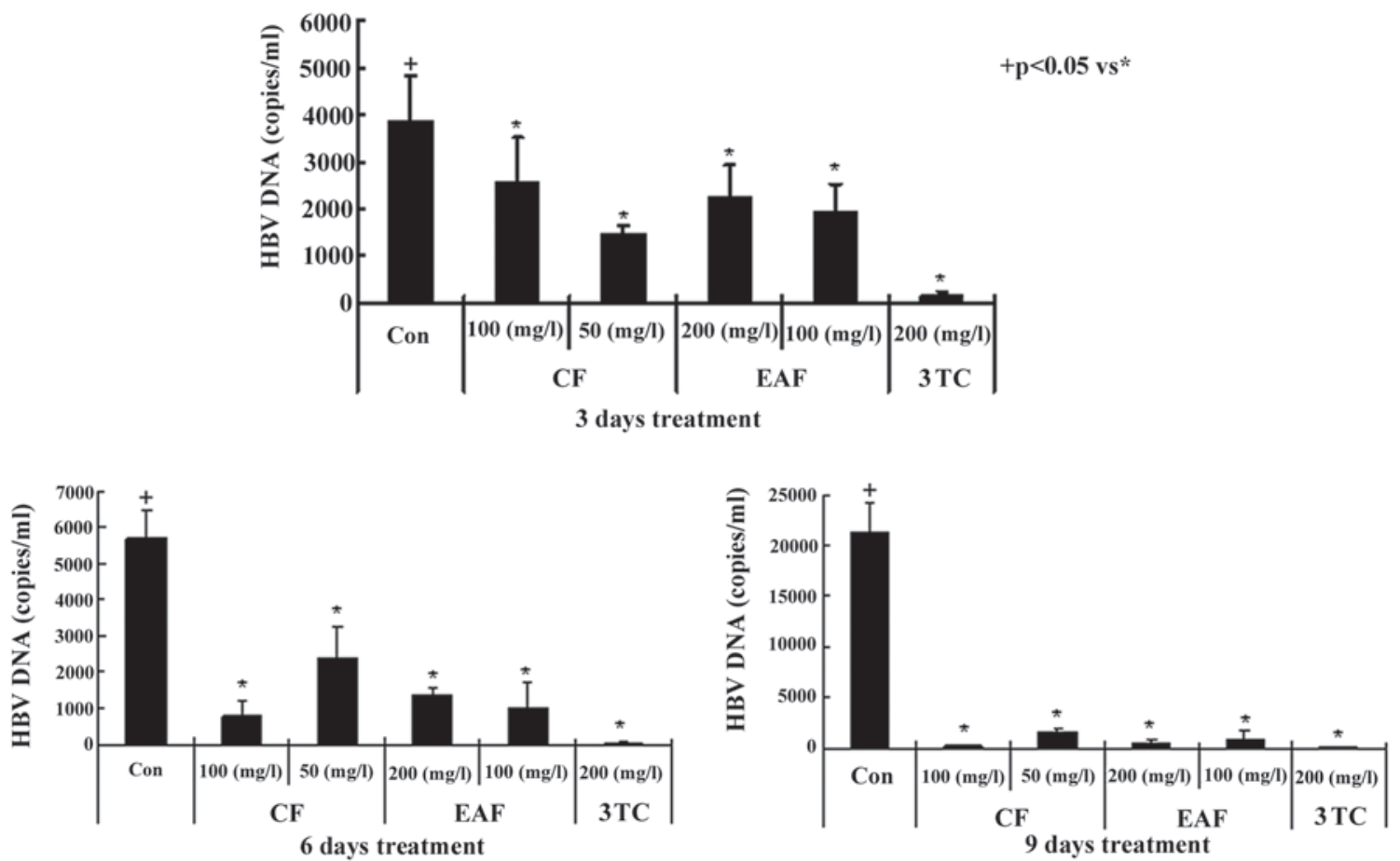

Figure 2. Effects of CF and EAF on HBV DNA in the medium secreted by HepG2.2.15 cells. A total of 1x104 cells were seeded in 96-well plates and cultured for $24 \mathrm{~h}$ prior to the addition of CF or EAF. The medium was changed three times every 3 days and replaced with fresh medium containing the corresponding extracts. At different time points (3, 6 or 9 days), medium was collected and the HBV DNA content was measured. Under the same conditions, 3 TC was used as a positive control. Con, control; CF, chloroform fraction; EAF, ethyl acetate fraction; HBV, hepatitis B virus; 3TC, 2'-3'deoxy-3'-thiocytidine.

Effects of CF and EAF on HBV DNA in the medium secreted by HepG2.2.15 cells. In order to determine the effects of CF and EAF on HBV DNA secretion by HepG2.2.15 cells, QF-PCR was performed. As shown in Fig. 2, CF and EAF were shown to significantly reduce the content of HBV DNA in the medium secreted by HepG2.2.15 cells compared to that of the control. These data indicated that $\mathrm{CF}$ and EAF inhibited HBV DNA replication. In addition, CF was shown to be more 
potent compared to EAF (Fig. 2). As a positive control, 3TC (200 $\mathrm{mg} / \mathrm{ml}$ ) reduced the content of HBV DNA in the medium secreted by HepG2.2.15 cells at 3, 6 and 9 days (Fig. 2).

BNL extracts exerted no cytotoxic effects on Hep G2.2.15 cells. To determine whether the anti-HBV effects of the BNL extracts were due to cytotoxicity, the effects of BNL extracts on HepG2.2.15 cell proliferation were assessed by the MTT assay. After 9 days of treatment, HepG2.2.15 cell growth was found to be unaffected by CF or EAF treatment (Tables II and III).

Chemical composition of BNL extracts. In order to determine the chemical composition of the BNL extracts, a qualitative assay was performed as previously described (5-7). The qualitative assay determined that PEF contained anthraquinones, phenols, volatile oils, steroids, terpenes, amino acids, reducing sugars, polysaccharides and organic acids; CF contained anthraquinones, phenols, steroids, terpenes, amino acids, organic acids, lactones and coumarins; EAF contained flavonoids, anthraquinones, phenols, lactones, coumarins, volatile oils, sterols, terpenes, amino acids, reducing sugars, polysaccharides and organic acids; $\mathrm{nBF}$ contained anthraquinones, phenols, lactone, coumarins, amino acids, reducing sugars and polysaccharides; and AF contained flavonoids, phenols, saponins, amino acids, reducing sugars, polysaccharides and organic acids.

\section{Discussion}

Boehmeria nivea, a perennial herbal plant with unique properties, contains multiple compounds of medicinal value. The production of Boehmeria nivea in China accounts for $>90 \%$ of its production worldwide; therefore, Boehmeria nivea is also referred to as 'China grass'. The bark of the Boehmeria nivea stem is used as a textile raw material (11); however, BNL, accounting for $\sim 40 \%$ of the plant's total weight (12) is wasted in the textile industry.

It was previously reported that the Boehmeria nivea root extract possesses anti-HBV properties (13) and a clinical trial on the anti-HBV effects of the Boehmeria nivea root extract in human subjects is currently underway. However, whether the BNL extract possesses similar properties has not been determined. In this study, the HBV-positive HepG2.2.15 cell line, which was able to secrete HBsAg, HBeAg and HBV DNA into the medium, was used to investigate the anti-HBV effects mediated by certain fractions extracted from BNL by different polarities. Of note, the inhibitory effect of AF extracted from BNL was similar to that of the $20 \%$ ethanol Boehmeria nivea root extract (5). Our results demonstrated that $\mathrm{CF}$ and $\mathrm{EAF}$ extracted from BNL significantly suppressed HBsAg and $\mathrm{HBeAg}$ secretion into the medium and inhibited HBV DNA replication in HepG2.2.15 cells, without any recorded cytotoxic effects. However, we were unable to specify which component of the BNL extract was key to the anti-HBV activity observed in this study. Therefore, the elucidation of the precise mechanisms underlying the anti-HBV effects of the BNL extract requires further investigation. The $\mathrm{CF}$ and $\mathrm{EAF}$, which exhibited the most potent anti-HBV activity, have several ingredients in common, including phenolic compounds, organic acids and terpenoids. Therefore, we deduced that phenolic compounds, organic acids (14) and terpenoids (15) may be the active components of the BNL extracts responsible for its anti-HBV properties. However, multiple mechanisms may be involved in this anti-HBV activity and future investigations should isolate, purifiy and identify the structure of the active compounds in the BNL extracts.

\section{Acknowledgements}

This study was supported in part by grants from the Traditional Medical Science and Technology Foundation from the Administration of Chinese Traditional Medicine of Guangxi Province (no. GZKZ-Z1107); the Open Fund of the Medical Scientific Research Center of Guangxi Medical University (nos. KFJJ2010-49 and KFJJ2011-06); the Lijiang Scholarship Foundation and the Science and Technology Planning Project of Guilin City (no. 20110119-1-8); the Natural Science Foundation of Guangxi Province (no. 2013GXNSFCA019012) and the National Natural Science Foundation of China (nos. 31370917 and 30972797). This study was also supported by a direct grant from the Guilin Medical University. The authors would like to thank Dr Junfei Jin for reviewing the manuscript.

\section{References}

1. Zhang GG, Zhao LN and Cheng JH: Medicinal value and development prospects of Ramie. Plant Fiber Sci China 24, 2002 (In Chinese).

2. Cai XF, Jin X, Lee D, et al: Phenanthroquinolizidine alkaloids from the roots of Boehmeria pannosa potently inhibit hypoxia-inducible factor-1 in AGS human gastric cancer cells. J Nat Prod 69: 1095-1097, 2006.

3. Yan J, Luo D, Luo Y, et al: Induction of G1 arrest and differentiation in MDA-MB-231 breast cancer cell by boehmeriasin A, a novel compound from plant. Int J Gynecol Cancer 16: 165-170, 2006.

4. Luo Y, Liu Y, Luo D, et al: Cytotoxic alkaloids from Boehmeria siamensis. Planta Med 69: 842-845, 2003.

5. Huang KL, Lai YK, Lin CC, et al: Inhibition of hepatitis B virus production by Boehmeria nivea root extract in HepG2 2.2.15 cells. World J Gastroenterol 12: 5721-5725, 2006.

6. Huang KL, Lai YK, Lin CC, et al: Involvement of GRP78 in inhibition of HBV secretion by Boehmeria nivea extract in human HepG2 2.2.15 cells. J Viral Hepat 16: 367-375, 2009.

7. Chang JM, Huang KL, Yuan TT, et al: The anti-hepatitis B virus activity of Boehmeria nivea extract in HBV-viremia SCID mice. Evid Based Complement Alternat Med 7: 189-195, 2010.

8. Semwal DK, Rawat U, Semwal R, et al: Chemical constituents from the leaves of Boehmeria rugulosa with antidiabetic and antimicrobial activities. J Asian Nat Prod Res 11: 1045-1055, 2009.

9. Sancheti S, Sancheti S and Seo SY: Evaluation of antiglycosidase and anticholinesterase activities of Boehmeria nivea. Pak J Pharm Sci 23: 236-240, 2010.

10. Lin CC, Yen MH, Lo TS, et al: Evaluation of the hepatoprotective and antioxidant activity of Boehmeria nivea var. nivea and B. nivea var. tenacissima. J Ethnopharmacol 60: 9-17, 1998.

11. Cheng XW: The history, status and future of ramie textile industry in China. Plant Fiber Sci China 29 (Suppl 1): S77-S85, 2007 (In Chinese).

12. Cao DH: Development and utilization of Ramie leaf. Spec Econ Anim Plant 4: 19, 2001 (In Chinese)

13. Li LZ, Zhang XF and Li CY: Drug treatment of liver diseases with plant extracts [P]. CN: 1634964, 2005.

14. Zhang JF, Tan J, Liu YH, et al: Advance in the research of herbs and natural products on antiviral against hepatitis B virus. Nat Prod Res Dev 14: 88-91, 2002 (In Chinese).

15. Liu HJ, Hu JH, Sun LN, et al: Inhibition effects of oleanolic acid from Chaenomeles lagenaria on hepatitis B virus in vitro. Pharm J Chin People's Liberation Army 18: 272-274, 2002 (In Chinese). 